\title{
Are estuaries traps for anthropogenic nutrients? Evidence from estuarine mesocosms
}

\author{
Barbara L. Nowicki, Candace A. Oviatt \\ Marine Ecosystems Research Laboratory, Graduate School of Oceanography, University of Rhode Island, Narragansett, \\ Rhode Island 02882-1197, USA
}

\begin{abstract}
A series of estuarine mesocosms is described, where nutrient budgets were used to determine rates of nitrogen and phosphorus trapping and export as a function of nutrient input level, season, and presence or absence of sediments. Regardless of treatment or season these experimental systems exported most of the $\mathrm{N}$ and $\mathrm{P}$ that they received. Control systems with sediments retained none of the inflowing $\mathrm{N}$ and $\mathrm{P}$ during summer, and $5 \%$ of $\mathrm{N}$ and $25 \%$ of $\mathrm{P}$ inputs during winter. Eutrophied systems with sediments initially retained $30 \%$ of added $N$ and $P$ due to increases in water column and sediment nutrient standing stocks in response to daily inorganic nutrient additions; however, after 6 mo of daily nutrient loading, these treatments retained only 5 to $15 \%$ of nutrients added. Results of this study suggest that well-mixed estuarine systems may export to offshore waters most of the nitrogen and phosphorus that they receive. For the small percentage of nutrients that were retained, there was more storage during winter than summer, more storage in treatments without sediments, and more retention of $P$ than $N$. Nitrogen losses through sediment denitrification accounted for 10 to $20 \%$ of the N input to controls, and less than $10 \%$ of the $\mathrm{N}$ input to eutrophied treatments. The addition of nutrients to the eutrophied treatments resulted in increases in the $\mathrm{N}$ and $\mathrm{P}$ content of surface sediments, and the rapid deposition of an $\mathrm{N}$ and P-rich detrital layer on the bottom of the treatments without sediments.
\end{abstract}

\section{INTRODUCTION}

The rapid growth of population centers in coastal areas of the USA over the past 50 yr has led to marked increases in anthropogenic inputs of nutrients, metals, and organic compounds to coastal waters (Jaworski 1981, Nixon et al. 1982, 1986, Nixon 1983, Hoffman \& Quinn 1984). Despite growing public concern about pollution and eutrophication surprisingly little is known about the ultimate fate of nutrients discharged to estuarine and coastal marine systems. Estuaries have been variously described as nutrient traps (Mansueti 1961, Schelske \& Odum 1961, Hedgpeth 1967, Odum 1971, Biggs \& Howell 1984), sinks (Hobbie et al. 1975 , Loder \& Glibert 1980, Smullen et al. 1982), buffers and filters (Schubel \& Kennedy 1984), and as exporters of nutrients to offshore waters (Odum 1971, Nixon et al. 1986, Nixon 1987), but despite a recent proliferation of research on estuaries and nutrients, there is little consensus on what becomes of the nutrients that estuaries receive.

The concept that estuaries serve as nutrient traps has been prevalent in the literature for many years

(C) Inter-Research/Printed in F. R. Germany
(Schelske \& Odum 1961, Hedgpeth 1967, Biggs \& Howell 1984). Mechanisms invoked to explain this trapping process have included the physical processes involved in 2-layer estuarine circulation (Pritchard 1955, Schubel \& Kennedy 1984), chemical flocculation and sedimentation in salinity mixing zones (Sholkovitz 1976), and biological processes of removal, including the transformation of dissolved nutrients into particulate form, and the removal of particles by filter-feeders in the water column and benthos (Schubel \& Kennedy 1984). However, recent reviews of data from the Chesapeake Bay (Nixon 1987) and Narragansett Bay (Nixon et al. 1986) suggest that these systems may retain only a small percentage of the nutrients that they receive annually, and these results conflict with the long-accepted belief that estuaries serve as nutrient traps. Although there is no doubt that nutrient transformation and trapping processes occur in estuarine systems it is unclear how important these processes are in the net removal of land-derived nutrient inputs. The capacity of coastal waters to trap, transform, and export nutrients may vary from one system to another, and from season to season within a given estuary (Peterson 
et al. 1975). To date, the information necessary to clearly define the role of most estuarine systems, regardless of whether they appear to function as nutrient traps or exporters, is unavailable. The extent to which offshore production is supported by estuarine outwelling of nutrients is also as yet unclear (Ketchum 1967, Riley 1967, Haines 1975, Dunstan \& Atkinson 1976, Hopkinson \& Hoffman 1984, Malone 1984, Nixon \& Pilson 1984).

A successful understanding of the role of estuaries as nutrient traps, filters, or exporters requires a knowledge of the distribution of dissolved and particulate nutrient species as well as their rates of input, loss, and accumulation in coastal waters. The nutrient budget or mass balance can be a useful tool in describing the fate of nutrients in estuaries. Nutrient budgets allow one to assess the relative importance of 'new' allochthonous nutrients versus internally recycled nutrients, can suggest the magnitude of nutrient export from a given system, and can provide a basis for comparison of one estuarine system to another. However despite the apparent usefulness of estuarine nutrient budgets very few have been published. While point-source inputs from rivers and sewage treatment plants have been successfully quantified for a number of systems (Peterson 1979, Loder \& Glibert 1980, Jaworski 1981, Smith 1981, Nixon et al. 1982, Smullen et al. 1982, Nixon 1983, Nixon \& Pilson 1983) the more spatially variable or sporadic inputs from groundwater seepage, surface runoff, precipitation, and offshore waters are much more difficult to measure. The potentially largest term in most estuarine nutrient budgets, the exchange of nutrients with offshore waters, is usually determined by difference or ignored due to difficulties involved in measuring small nutrient exchange differences in relatively large tidal volumes (Boon 1978, Kjerfve et al. 1982). In addition, nutrient accumulation rates in estuarine sediments are difficult to measure against the large background of $\mathrm{C}, \mathrm{N}$, or $\mathrm{P}$ already present, and are complicated by resuspension, bioturbation, and deposition rates that vary widely over time and location.

The intention of this study was to use a nutrient mass balance approach to determine whether the MERL mesocosms, a series of model estuarine systems, were behaving as nutrient traps. Experiments were designed to examine the role of the bottom sediments, and the impact of eutrophication on nutrient trapping efficiency. Estuarine mesocosms were used to circumvent the problems involved in preparing nutrient budgets for natural coastal systems.

The mesocosms at the Marine Ecosystem Research Laboratory in Rhode Island have been operated as estuarine models in a number of experimental modes over the past $12 \mathrm{yr}$. Previous studies have shown that mesocosms designated as 'controls' are similar to adja- cent Narragansett Bay with respect to observed concentrations of metals, nutrients, and organic compounds (Pilson et al. 1979, 1980, Hunt \& Sinith 1982, Santschi 1982, Wakeham et al. 1982, Pilson 1985a), and in species composition and abundance (Elmgren \& Frithsen 1982), and with respect to respiration and production by the water column and benthos (Oviatt et al. 1981). This article presents the results of nutrient mass balances for control and eutrophied mesocosms, with and without sediment communities, and describes experiments designed to determine to what extent $N$ and $P$ were trapped or exported as a function of different levels of nutrient input, and relative to the presence or absence of a sediment community. Nutrient budgets were prepared for 6 mesocosms by quantifying all sources and sinks of inorganic and organic dissolved and particulate $N$ and $P$. Measurements included inputs of $N$ and $P$ in inflowing water from adjacent Narragansett Bay, in rain, snow, and atmospheric dry deposition ('dryfall'), and outputs of $\mathrm{N}$ and $\mathrm{P}$ in outflowing water, in losses to denitrification, to burial, and to increases in biomass. This paper documents the relative proportions of $\mathrm{N}$ and $\mathrm{P}$ trapped or exported by the mesocosms as a function of treatment. A second paper (Nowicki unpubl.) will describe the fate of nutrients retained within the mesocosms.

\section{METHODS}

Experimental design. The mesocosms were flowing water systems (5 $\mathrm{m}$ deep, volume of 13150 l) located outdoors in natural sunlight and maintained yearround at temperatures within $2^{\circ} \mathrm{C}$ of adjacent Narragansett Bay. Water inflow to the mesocosms from lower Narragansett Bay occurred 4 times per day and was sufficient to replace the volume of water in each meso$\operatorname{cosm}$ once every $27 \mathrm{~d}$. This flushing rate was chosen because it is similar to estimated average flushing times for adjacent Narragansett Bay (Pilson 1985b). The mesocosms were mixed with a plunger-type mixer on a continuous schedule of $2 \mathrm{~h}$ on and $4 \mathrm{~h}$ off (Fig. 1). Turbulence was scaled to provide an average suspended particle load in the mesocosms ( $3.5 \mathrm{mg} \mathrm{l}^{-1}$ ) that was similar to that of Narragansett Bay $\left(5 \mathrm{mg} \mathrm{l}^{-1}\right)$. The walls of the mesocosms were scrubbed twice a week in summer, and weekly in winter, to prevent the accumulation of fouling organisms.

To examine the role of the sediments in estuarine nutrient trapping efficiency, nutrient budgets were compiled for mesocosms with and without sediment communities. Mesocosms with sediments contained an intact sediment community, $37 \mathrm{~cm}$ deep, taken from adjacent Narragansett Bay, while those without sediments contained only detrital material which settled 


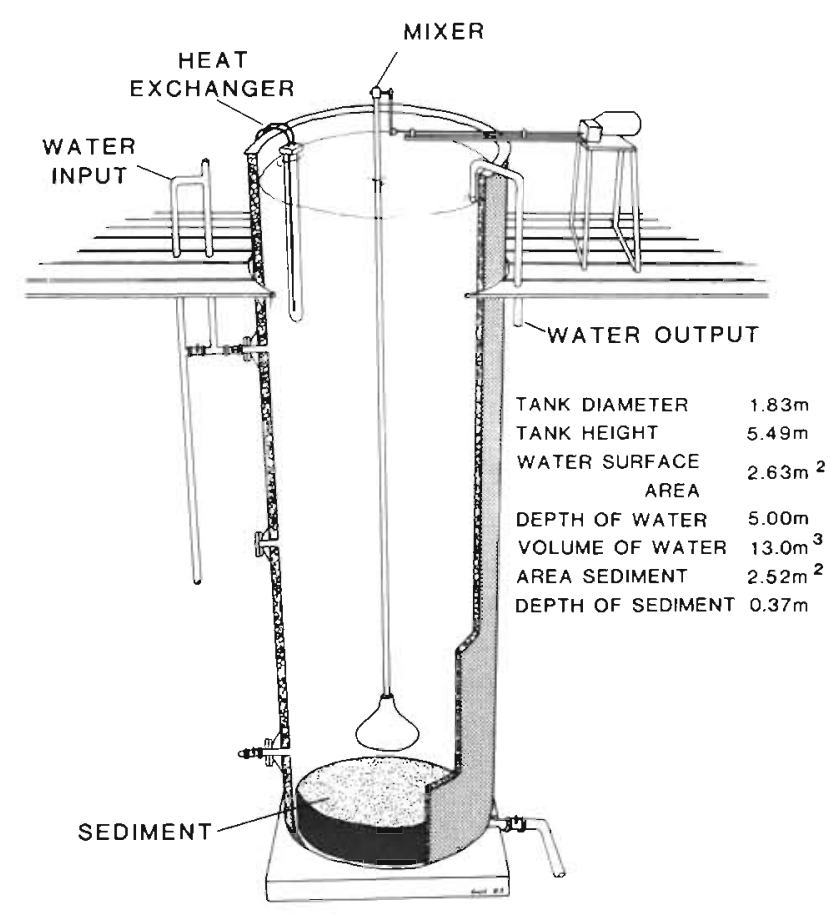

Fig. 1. A mesocosm

from the overlying water column and was allowed to accumulate on the bottom. The bottoms of these 'NoSediment' treatments were brushed every $2 \mathrm{wk}$ by divers to prevent recruitment and the development of a macrofaunal community.

All of the mesocosms received nutrients in the daily inflow of lower Narragansett Bay water, and from rain, snow, or dryfall. In addition, 4 of the 6 experimental systems received a daily inorganic nutrient addition (Lambert \& Oviatt 1986) designed to provide systems where the impact of eutrophication on nutrient trapping capacity could be examined. Two mesocosms received a daily nutrient addition of $\mathrm{NH}_{4}$ as $\mathrm{NH}_{4} \mathrm{Cl}_{4} \mathrm{PO}_{4}$ as $\mathrm{KH}_{2} \mathrm{PO}_{4}$, and $\mathrm{SiO}_{3}$ as $\mathrm{Na}_{2} \mathrm{SiO}_{3}$ equivalent to 8 times the area-weighted sewage input of dissolved inorganic nutrients to Narragansett Bay (Nixon 1981). The $8 \times$ nutrient addition was approximately equal to sewage nutrients in the Providence River estuary at the head of Narragansett Bay. In addition, 2 of the mesocosms received this same $8 \times$ treatment of ammonia and phosphate, but also additional silica so that the addition of silica was equal to that of ammonia (Fig. 2). The $8 x+\mathrm{Si}$ treatments stimulated a diatom-dominated rather than a flagellate-dominated plankton community as a consequence of eutrophication (Doering et al. 1989). Although the addition of silica to the $8 x+$ Si treatments did enhance diatom standing stocks, it had little effect on rates of production or metabolism (Doering et al. 1989), and there were no statistically significant differences between nutrient budgets for the $8 \times$ and $8 \times+\mathrm{Si}$ treatments. Consequently, results for these 2 eutrophied treatments have been combined for comparison with the control. Detailed descriptions of the nutrient budgets for each of the individual treatments can be found in Nowicki (1990).

Daily nutrient additions began on June 11, 1985, and continued for $1 \mathrm{yr}$. Nutrient budgets were prepared for one $62 \mathrm{~d}$ period in summer (July 18 to September 17. 1985) and one $62 \mathrm{~d}$ period during winter (January 10 to March 12, 1986) to address seasonal and temperature related effects.

Nutrient budgets. Terms in the budgets included nutrients in water from lower Narragansett Bay, in precipitation and atmospheric dryfall, and in experimental nutrient additions, and the loss of nutrients in outflowing water, to denitrification, and to changes in standing stock and biomass. Nutrient concentrations in the water from Narragansett Bay were measured immediately prior to introduction to the mesocosms, 3 times a week, from a $24 \mathrm{~h}$ composite nutrient sample. The volume of water flowing to the mesocosms was monitored weekly and used with $24 \mathrm{~h}$ composite nutrient concentrations to estimate the daily flow of $\mathrm{N}$ and $\mathrm{P}$ to the mesocosms in the Bay water. The flow of Bay water into the mesocosms displaced an equal volume (ca $1 \%$ of mesocosm volume every $6 \mathrm{~h}$ ) as water flushed out of each system 4 times per day. During this

\begin{tabular}{|c|c|c|c|}
\hline & CONTROL & $8 x$ & $8 X+51$ \\
\hline Sediments & $\begin{array}{c}\text { No } \\
\text { Additions }\end{array}$ & $\begin{array}{l}\mathrm{NH} 3=60 \mathrm{mmol} / \text { day } \\
\mathrm{PO} 4=5 \mathrm{mmol} / \text { day } \\
\mathrm{SIO} 3=4.3 \mathrm{mmol} / \text { day }\end{array}$ & $\begin{array}{l}\mathrm{NH} 3=60 \mathrm{mmo} / \mathrm{day} \\
\mathrm{PO} 4=5 \mathrm{mmol} / \mathrm{day} \\
\mathrm{SIO} 3=60 \mathrm{mmol} / \text { day }\end{array}$ \\
\hline No-Sediments & $\begin{array}{c}\text { No } \\
\text { Additions }\end{array}$ & $\begin{array}{l}\mathrm{NH} 3=60 \mathrm{mmol} / \text { day } \\
\mathrm{PO} 4=5 \mathrm{mmol} / \mathrm{day} \\
\mathrm{SIO} 3=4.3 \mathrm{mmol} / \mathrm{day}\end{array}$ & $\begin{array}{l}\mathrm{NH} 3=60 \mathrm{mmol} / \text { day } \\
\mathrm{PO} 4=5 \mathrm{mmol} / \mathrm{day} \\
\mathrm{SIO} 3=60 \mathrm{mmol} / \mathrm{day}\end{array}$ \\
\hline
\end{tabular}

Fig. 2. Nutrient budgets were prepared for mesocosms with and without sediment communities at 3 levels of nutrient input. Daily inorganic nutrient additions to the $8 \times$ and $8 x+$ Si treatments are shown in units of $\mathrm{mmol}$ mesocosm ${ }^{-1} \mathrm{~d}^{-1}$ 
period the mesocosms were constantly mixed. Preliminary work showed that nutrient concentrations were homogeneous in the mesocosms during mixing, and that sampling each system 3 times per week was sufficient to give an accurate estimate of daily nutrient concentrations in the outflowing water.

To calculate the error associated with estimates of nutrients flowing into and out of the mesocosms an equation (Ramette 1981) for calculating the variance of the product of 2 unknowns (flow $\times$ concentration) was used. Most of the errors associated with estimates of nutrient flux were due to variations observed in flow volumes. With 2 exceptions, flow to the mesocosms varied by less than $4 \%$ over the $9 \mathrm{wk}$ budget period. However during the summer period, flow to the $8 \times /$ No-Sediment treatment varied by $5 \%$, and by $10 \%$ to the $8 \times+\mathrm{Si} / \mathrm{No}$-Sediment treatment, and this larger flow variation was reflected in larger error terms for the flow to and from these mesocosms for the summer budgets

For the $8 \times$ and $8 x+$ Si treatments the error associated with inflow was smaller than the error in outflow because average daily nutrient concentrations in the inflowing Bay water were significantly lower than those maintained in the eutrophied treatments. The control mesocosms maintained nutrient concentration levels very close to those observed in the Bay water, so errors in the inflow and outflow terms were similar. For all mesocosms, inflow errors were calculated separately from outflow errors even though the 2 terms were not strictly independent from one another. Because the inflow of water to the mesocosms displaced an equal volume as outflow, the errors in these 2 terms tend to cancel one another. Consequently, the confidence limits given in the budgets should be considered as upper estimates.

Rain and snowfall were collected in $500 \mathrm{ml}$ polybottles fitted with glass funnels $(10 \mathrm{~cm}$ diameter $)$ inserted through a stopper in the bottle neck. Replicate samplers were acid-cleaned $(2 \mathrm{~N} \mathrm{HCl})$, rinsed with deionized water, and mounted outside on the north and south sides of the mesocosms immediately prior to each precipitation event. Samplers remained outside for the duration of a storm, and were then retrieved and the collected precipitation analyzed for dissolved inorganic and organic $\mathrm{N}$ and $\mathrm{P}$. The volumes collected were calculated pro rata for the surface areas of the mesocosms. Confidence limits for estimates of the total $\mathrm{N}$ and $\mathrm{P}$ added to the mesocosms in rain and snowfall were based on the summed squares of standard deviations (Ramette 1981) for replicate measurements of 9 precipitation events during the summer budget period, and 12 events during the winter period. Atmospheric dryfall was estimated from increases in $\mathrm{N}$ and $\mathrm{P}$ concentration observed in filtered $(0.45 \mu \mathrm{m})$ Bay water held in open rectangular $(33 \times 27 \mathrm{~cm})$ collectors and preserved with chloroform to prevent biological uptake or release of nutrients.

Changes in nutrient standing stocks in sediments were estimated from changes in the $\mathrm{N}$ and $\mathrm{P}$ concentration in the surface centimeter of replicate cores taken from each mesocosm at the beginning, middle and end of the budget periods. In treatments without sediments, samples were taken of the detrital material collecting on the mesocosm bottom (Doering 1989). Subsamples $\left(0.049 \mathrm{~m}^{2}\right)$ of the accumulating detritus were analyzed for total $\mathrm{N}$ and $\mathrm{P}$ every $2 \mathrm{wk}$ in summer and monthly during winter.

In the water column, fluctuations in nutrient concentrations were rapid relative to the 2 mo budget periods, and differences in observed concentrations on the first and last days of the budget periods were not always representative of true longer term changes in standing stock. Consequently, plots of total $\mathrm{N}$ and total $\mathrm{P}$ concentrations over time for each treatment were fit to linear regressions, and the regressions were used to predict standing stock concentrations at the beginning and end of each budget period. The errors in these estimates were based on the variability in water column concentrations for 5 consecutive days at the beginning and end of each period.

The loss of fixed nitrogen as $\mathrm{N}_{2}$ gas through sediment denitrification was estimated from the flux of $\mathrm{N}_{2}$ gas from intact sediment cores placed in $\mathrm{N}_{2}$-free gas-tight chambers (Seitzinger et al. 1984, Nowicki unpubl.). Repeated time-series measurements of $\mathrm{N}_{2}$ gas flux were made on sediment cores taken during the budgeting periods. The errors shown for the denitrification terms given in the budgets were based on average coefficients of variation for replicate cores.

Estimates of denitrification rates for the No-Sediment treatments could not be obtained because of the difficulty involved in gathering intact representative layers of the flocculant debris accumulating on the mesocosm bottoms. For the purposes of the nutrient mass balances denitrification rates for the $8 \times$ and $8 \times+$ Si/No-Sediment treatments were assumed to be the same as those observed for corresponding treatments with sediments. In the control mesocosm without sediments, flocculant debris accumulated on the bottom very slowly, and only during the winter budget period was there sufficient accumulation to suggest that denitrification might have occurred there.

Analytical techniques. Samples taken for dissolved inorganic nutrients were filtered immediately (precombusted Whatman GF/C, $1.2 \mu \mathrm{m}$, glass fiber filters), preserved with $0.001 \%$ chloroform, and stored at $4{ }^{\circ} \mathrm{C}$ until analysis. These samples were analyzed for ammonia, nitrate plus nitrite, and phosphate using a Technicon Autoanalyzer (Lambert \& Oviatt 1986). Samples for 
total dissolved and particulate $\mathrm{N}$ and $\mathrm{P}$ were treated immediately with a persulfate digestion (Valderrama 1981, Lambert \& Oviatt 1986) and then analyzed for inorganic $\mathrm{N}$ and $\mathrm{P}$ using a Technicon Autoanalyzer. The analytical precision ( $\pm 1 \mathrm{SD}$ ) for total nitrogen was $0.3 \mu \mathrm{g}$-at. $\mathrm{l}^{-1}$ and for total phosphorus was $0.04 \mu \mathrm{g}$-at. $1^{-1}$. The nitrogen content of surface sediments and of the detritus collected from No-Sediment treatments was determined using a Carlo Erba Model $1106 \mathrm{CHN}$ analyzer. Sediment and detrital $\mathrm{P}$ content was determined, following combustion at $450^{\circ} \mathrm{C}$, with a $1 \mathrm{~N} \mathrm{HCl}$ extraction (Beach 1981, Froelich et al. 1982).

\section{RESULTS}

\section{Narragansett Bay water}

The flow of water to the mesocosms from lower Narragansett Bay was equal to slightly less than $4 \%$ of each mesocosm's volume per day. Aside from the inorganic nutrient addition to the nutrient treatments, it was the largest nutrient input to the mesocosms, contributing an average of $850 \mathrm{mg}$-at. $\mathrm{N}$ per mesocosm (320 $\mathrm{mg}$-at. $\mathrm{N} \mathrm{m}^{-2}$ ) and $105 \mathrm{mg}$-at. $\mathrm{P}$ per mesocosm (40 mg-at, $\mathrm{P} \mathrm{m} \mathrm{m}^{-2}$ ) in summer and $530 \mathrm{mg}$-at. $\mathrm{N}$ per mesocosm (200 mg-at. $\mathrm{N} \mathrm{m}^{-2}$ ) and $60 \mathrm{mg}$-at. $\mathrm{P}$ per mesocosm (20 mg-at. $\mathrm{P} \mathrm{m}^{-2}$ ) in winter (Table $1 \mathrm{a}$ to $\mathrm{d}$ ). Nutrient concentrations in the Bay varied seasonally, and Bay water nutrient inputs to the mesocosms were smaller in winter, during the winter-spring bloom, than in summer. Because of this variable input of nutrients from the Bay, the $8 x$ and $8 x+$ Si treatments actually received 5 times the $N$ and 4 times the $P$ received by the controls during the summer period, and 7 times the $N$ and 5 times the $P$ received by the controls in the winter. Nitrogen in the Bay water was present primarily as dissolved organic nitrogen (DON, 55\%) and particulate nitrogen (PN, 30 to $40 \%$ ). Phosphorus species were equally divided between inorganic phosphate, dissolved organic phosphorus (DOP) and particulate phosphorus (PP) in summer, with less inorganic phosphate and more DOP in winter.

\section{Atmospheric inputs}

Although contributions from rain, snow and dryfall were small relative to other inputs $(3$ to $5 \%$ of the $\mathrm{P}$ and $10 \%$ of the $\mathrm{N}$ input to controls, and 1 to $2 \%$ of the total $\mathrm{N}$ and $\mathrm{P}$ input to the $8 \times$ and $8 \times+\mathrm{Si}$ treatments; Table $1 \mathrm{a}$ to $\mathrm{d})$ they were a significant source of inorganic nitrogen $\left(\mathrm{NH}_{4}+\mathrm{NO}_{3}+\mathrm{NO}_{2}\right)$ to the controls. Because the flow of Bay water to the mesocosms was composed primarily of DON and PN, wet and dry atmospheric deposition of ammonia and nitrate were important sources of dissolved inorganic nitrogen (DIN) to controls, comprising $47 \%$ of the DIN input to the controls in summer and $82 \%$ of the DIN input in winter Atmospheric inputs were especially important as a source of inorganic $N$ to controls in winter when Bay water contributions of DIN were decreased by the winter-spring bloom in the Bay.

Rain and snow contributed primarily nitrate and ammonia and only small amounts of phosphate. Nitrate and ammonia concentrations in wet precipitation ranged from 1.5 to $100($ mean $=37) \mu \mathrm{g}$-at. $\mathrm{l}^{-1}$ and 0.5 to $80($ mean $=15) \mu g$-at. $l^{-1}$, respectively, while phosphate concentrations ranged from 0 to $0.5($ mean $=0.1)$ $\mu \mathrm{g}$-at. $\mathrm{l}^{-1}$. There was considerable variation in the amount of $\mathrm{N}$ or $\mathrm{P}$ contributed by precipitation collected on different days, and there was no relationship between the total volume of precipitation collected for each event and corresponding nutrient concentrations, although nutrient concentrations tended to be highest in the precipitation collected within the first few hours of a storm. During the winter budget period, precipitation was analyzed for DON and DOP as well as for inorganic nutrients. While DOP inputs were often nondetectable ( 0 to $0.06 \mathrm{mg}$-at. $\mathrm{P} \mathrm{m}^{-2}$ per storm), DON inputs $\left(0.04\right.$ to $0.5 \mathrm{mg}$-at. $\mathrm{N} \mathrm{m}^{-2}$ per storm) contributed 25 to $45 \%$ of total nitrogen added by precipitation. The DON concentration of wet precipitation was strongly correlated with its $\mathrm{NO}_{3}$ concentration $\left(\mathrm{r}^{2}=0.988\right.$, Fig. 3) and also somewhat correlated with its $\mathrm{NH}_{3}$ concentration $\left(r^{2}=0.83\right)$. A linear regression was used to predict DON inputs in precipitation for days during the winter budget period when no samples for DON were collected (Fig. 3). The total contribution of rain and snow derived nitrogen was $60 \%$ higher in the summer than in the winter due to higher summertime ammonia concentrations and to increases in the volume of precipitation received.

Observations of atmospheric dry deposition on 4 occasions in summer were fairly consistent for $\mathrm{NO}_{3}$ $\left(0.10 \mathrm{mg}\right.$-at. $\mathrm{N} \mathrm{d}^{-1}$ per mesocosm $\left.\pm 27 \%\right)$ and for $\mathrm{PO}_{4}$ (0.05 mg-at. $\mathrm{P} \mathrm{d}^{-1}$ per mesocosm $\pm 30 \%$ ) but highly variable for $\mathrm{NH}_{3}$ (mean $=0.3 \mathrm{mg}$-at. $\mathrm{N} \mathrm{d}^{-1}$ per mesocosm $\pm 69 \%$, range $=0.01$ to 0.56 ). Replication for duplicate samples from the north and south sides of the mesocosm area on any given day was better than for samples collected on different days. Dryfall was estimated to contribute 20 to $30 \mathrm{mg}$-at. $\mathrm{N}$ and 2 to $4 \mathrm{mg}$-at. $\mathrm{P}$ per mesocosm per $62 \mathrm{~d}$ (Table $1 \mathrm{a}$ to $\mathrm{d}$ ).

\section{Denitrification}

Nitrogen losses through sediment denitrification accounted for less than $10 \%$ of the nitrogen input to the 
Table 1. Summer (July 18 to September 17,1985 ) and winter (January 10 to March 12,1986 ) budgets for total $N$ and total $P$, Units are mg-at. $\mathrm{N}$ or $\mathrm{P}$ per mesocosm per $62 \mathrm{~d}$. The area of the $5 \mathrm{~m}$ deep mesocosms was $2.63 \mathrm{~m}^{2}$. Total $\mathrm{N}$ includes $\mathrm{NH}_{3}, \mathrm{NO}_{3}, \mathrm{NO}_{2}$, DON, and PN and total $\mathrm{P}$ includes $\mathrm{PO}_{4}, \mathrm{DOP}$, and PP. The error terms represent $95 \%$ confidence intervals. Increases in nutrient standing stocks are shown with a $(+)$ sign and decreases with a $(-)$ sign. ND: non-detectable. No denitrification measurements were made in the No-Sediment treatments; however for purposes of calculation, rates for the treatments with sediments were included in budgets for the No-Sediment treatments

\begin{tabular}{|c|c|c|c|c|}
\hline \multirow{2}{*}{ a. Summer nitrogen bu } & \multicolumn{2}{|c|}{ Control } & \multicolumn{2}{|c|}{$8 x$ and $8 x+\mathrm{Si}$} \\
\hline & Sed. & No-Sed. & Sed. & No-Sed. \\
\hline \multicolumn{5}{|l|}{ Inputs } \\
\hline$\overline{\text { Inflow }}$ water & $820( \pm 16)$ & $890( \pm 19)$ & $820( \pm 18)$ & $870( \pm 42)$ \\
\hline Rain/snow & $50( \pm 2)$ & $50( \pm 2)$ & $50( \pm 2)$ & $50( \pm 2)$ \\
\hline Dryfall & $30( \pm 24)$ & $30( \pm 24)$ & $30( \pm 24)$ & $30( \pm 24)$ \\
\hline Nutrient add. & 0 & 0 & $3755( \pm 19)$ & $3755( \pm 19)$ \\
\hline Total input & $900( \pm 30)$ & $970( \pm 30)$ & $4655( \pm 35)$ & $4705( \pm 50)$ \\
\hline \multicolumn{5}{|l|}{ Outputs } \\
\hline Outflow water & $950( \pm 20)$ & $925( \pm 20)$ & $2915( \pm 60)$ & $2875( \pm 140)$ \\
\hline Denitrification & $200( \pm 75)$ & 0 & $400( \pm 150)$ & $400( \pm 150)$ \\
\hline Totãl output & $1150( \pm 75)$ & $925( \pm 20)$ & $3315( \pm 160)$ & $3275( \pm 205)$ \\
\hline Retained in mesocosm & 0 & 45 & 1340 & 1430 \\
\hline \multicolumn{5}{|l|}{$\triangle$ Standing stock } \\
\hline Water column & $-200( \pm 40)$ & ND & $+300( \pm 70)$ & $+225( \pm 40)$ \\
\hline Sediments & ND & $+160( \pm 65)$ & $+600( \pm 140)$ & $+1000( \pm 465)$ \\
\hline$\frac{\text { Total input }}{+ \text { Std stock decreases }}$ & $1100( \pm 50)$ & $970( \pm 30)$ & $4655( \pm 35)$ & $4705( \pm 50)$ \\
\hline Total output & $1150( \pm 75)$ & $1085( \pm 70)$ & $4215( \pm 225)$ & $4500( \pm 515)$ \\
\hline
\end{tabular}

b. Summer phosphorus budget

Sed. Control No-Sed. Sed. $\quad$ No-Sed.

\section{Inputs}

Inflow water

Rain/snow

Dryfall

Nutrient add.

Total input

Outputs

Total output

(Outflow water)

Retained in mesocosm

$\triangle$ Standing stock

Water column

Sediments

Total input

+ Std stock decreases

Total output

+ Std stock increases

$\begin{array}{cc}100( \pm 2) & 110( \pm 3) \\ 0.2( \pm 0.01) & 0.2( \pm 0.01) \\ 3( \pm 2) & 3( \pm 2) \\ 0 & 0 \\ \frac{105}{105}( \pm 3) & 115( \pm 3)\end{array}$

$105( \pm 2)$

0

ND

ND

$105( \pm 3)$

$105( \pm 2)$

ND

$+15( \pm 6)$

$115( \pm 3)$

$100( \pm 6)$

$100( \pm 3)$
$0.2( \pm 0.01)$
$3( \pm 2)$
$\frac{293}{395}( \pm 2)$
$( \pm 4)$

$105( \pm 6)$

$0.2( \pm 0.01)$

$3( \pm 2)$

$293( \pm 2)$

$400( \pm 7)$

$255( \pm 13)$

$280( \pm 6)$

115

145

$+45( \pm 15)$

$+30( \pm 30)$

$+30( \pm 15)$

$395( \pm 4)$

$+50( \pm 30)$

$355( \pm 35)$

$400( \pm 7)$

$335( \pm 35)$ eutrophied treatments and 10 to $20 \%$ of the nitrogen input to the controls (Table 1a, c). Denitrification represented a large loss of the $N$ remaining in the mesocosms after losses in the outflowing water were taken into account. During the budget periods rates of denitrification ranged from 10 to $30 \mu \mathrm{mol} \mathrm{N} \mathrm{N}^{-2} \mathrm{~h}^{-1}$ for control sediments and from 40 to $60 \mu \mathrm{mol} \mathrm{N} \mathrm{m}^{-2} \mathrm{~h}^{-1}$ for $8 x$ and $8 x+$ Si sediments over a temperature range 
Table 1 (continued)

c. Winter nitrogen budget



from 4 to $22^{\circ} \mathrm{C}$. The rates appear to have doubled during the year-long course of nutrient additions (Table 2).

Sediment cores that were used for measurements of denitrification were maintained in an $\mathrm{N}_{2}$-free environment, at ambient temperature and overlying water column nutrient concentrations, for 5 to $6 \mathrm{~d}$ before beginning measurements, in order to flush remaining $\mathrm{N}_{2}$ gas from sediment pore waters (Seitzinger et al. 1984). Whether this 5 to $6 \mathrm{~d}$ waiting period had an impact on observed rates of $\mathrm{N}_{2}$ gas production is unknown. Measurements made more than $2 \mathrm{wk}$ after 


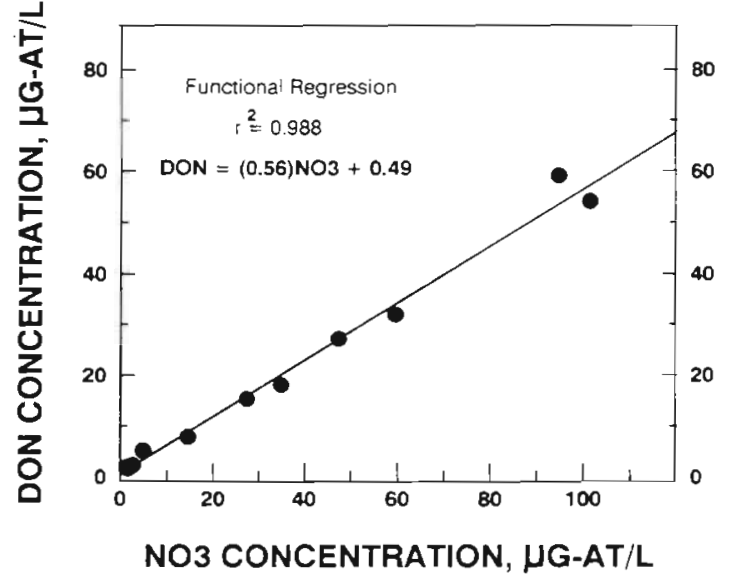

Fig. 3. A linear relationship was found between the concentration of DON and the concentration of $\mathrm{NO}_{3}$ in wet precipitation

core collection tended to be lower than those obtained earlier (Table 2).

\section{Nutrient export versus storage}

The budgets suggest that the mesocosms exported in outflowing water most of the $\mathrm{N}$ and $\mathrm{P}$ that they received regardless of treatment or season. The control mesocosm with sediments retained none of the $\mathrm{N}$ or $\mathrm{P}$ added from Bay water and precipitation during the summer period, and $5 \%$ of the $\mathrm{N}$ and $25 \%$ of the $\mathrm{P}$ added during the winter (Fig. 4). The control without sediments retained $5 \%$ of the $\mathrm{N}$, and $25 \%$ of the $\mathrm{P}$ added from Bay water and precipitation during the summer, and $20 \%$ of the $\mathrm{N}$ and $45 \%$ of the $\mathrm{P}$ added in winter. In general, there was more storage of nutrients in the winter than in summer, and more storage in the NoSediment control than in the control with sediments, although in the No-Sediment treatment the amount of $N$ ultimately lost to denitrification is unknown. There was also more retention of $P$ than $N$, particularly in the control without sediments (Fig. 4). In the control with sediments the greater retention of $\mathrm{P}$ than $\mathrm{N}$ was due primarily to the selective loss of $N$ through denitrification. In the No-Sediment treatment, 20 to $25 \%$ more $\mathrm{P}$ than $\mathrm{N}$ remained in the system in excess of the $\mathrm{N}$ that was stored or denitrified. Nevertheless, most of the $\mathrm{N}$ and $P$ added to the control mesocosms from Bay water and precipitation was lost in the outflowing water (Fig. 4).

The $8 \times$ and $8 x+$ Si treatments stored or denitrified 35 to $40 \%$ of $\mathrm{N}$ added and 30 to $35 \%$ of $\mathrm{P}$ added in summer, and 15 to $20 \%$ of $\mathrm{N}$ added and 10 to $15 \%$ of $\mathrm{P}$ added in winter (Fig. 5). The increased storage in summer versus winter was due to increases in water
Table 2. Observed rates of denitrification (umol $\mathrm{N}_{2} \mathrm{~m}^{-2} \mathrm{~h}^{-1}$ ) for intact sediment cores obtained from the mesocosms during the year-long nutrient addition experiment. Rates shown are the slopes of linear regressions of $\mathrm{N}_{2}$ concentration versus time in the overlying gas phase of sealed incubation chambers. When 2 numbers are given for a single time period they represent $\mathrm{N}_{2}$ fluxes for duplicate cores

\begin{tabular}{|c|c|c|c|c|c|}
\hline $\begin{array}{l}\text { Date of core } \\
\text { collection }\end{array}$ & $\begin{array}{l}{ }^{\circ} \mathrm{C} \\
\text { Temp. }\end{array}$ & $\begin{array}{c}\text { Days } \\
\text { since } \\
\text { coring }\end{array}$ & Control & $8 x$ & $8 x+S i$ \\
\hline Aug 22, 1985 & 22.0 & 15 & - & 52 & 58 \\
\hline Sep 11, 1985 & 22.0 & 7 & 27 & - & 58 \\
\hline \multirow[t]{3}{*}{ Feb 20, 1986} & 4.0 & 6 & $\begin{array}{r}11 \\
9\end{array}$ & 48 & 39 \\
\hline & 4.5 & 22 & $\begin{array}{r}11 \\
0\end{array}$ & 21 & 29 \\
\hline & 5.4 & 48 & $\begin{array}{l}0 \\
0\end{array}$ & 0 & 0 \\
\hline May 21, 1986 & 12.5 & $\begin{array}{r}6 \\
8 \\
14\end{array}$ & $\begin{array}{r}56 \\
60 \\
0\end{array}$ & $\begin{array}{r}104 \\
114 \\
97\end{array}$ & $\begin{array}{r}103 \\
76 \\
66\end{array}$ \\
\hline \multirow[t]{3}{*}{ Sep 22, 1986} & 18.0 & 5 & - & $\begin{array}{l}226 \\
182\end{array}$ & - \\
\hline & & 7 & - & $\begin{array}{l}217 \\
183\end{array}$ & - \\
\hline & & 9 & - & $\begin{array}{l}221 \\
179\end{array}$ & - \\
\hline \multirow[t]{4}{*}{ Oct 14,1986} & 18.0 & 7 & $\begin{array}{l}48 \\
40\end{array}$ & - & - \\
\hline & & 9 & - & - & - \\
\hline & & 10 & $\begin{array}{l}49 \\
44\end{array}$ & - & - \\
\hline & & 12 & $\begin{array}{l}53 \\
43\end{array}$ & - & - \\
\hline
\end{tabular}

column and sediment standing stocks following the onset of daily inorganic nutrient additions. The inorganic nutrient additions caused the standing stock of nutrients in the water column of the $8 x$ and $8 x+\mathrm{Si}$ treatments to increase steadily following each daily addition. In a volume of $13 \mathrm{~m}^{3}$ with a flushing time of $27 \mathrm{~d}$ the water column in the mesocosms would be expected to reach an equilibrium concentration, barring any uptake by the sediments or losses to denitrification, after about 3 mo of daily nutrient additions. The summer nutrient budget period began $1 \frac{1}{2}$ mo after the start of nutrient additions, and thus the observed summer nutrient retention in the eutrophied treatments was due primarily to increases in nutrient standing stocks in response to the large inorganic nutrient loading, rather than to seasonal differences.

Overall, 60 to $70 \%$ of the $\mathrm{N}$ and $\mathrm{P}$ added to the eutrophied systems was exported in the outflowing water during the summer. In the winter, 80 to $90 \%$ of the added nutrients were exported. There was no statistically significant difference in the nutrient reten- 


\section{CONTROL MESOCOSMS}

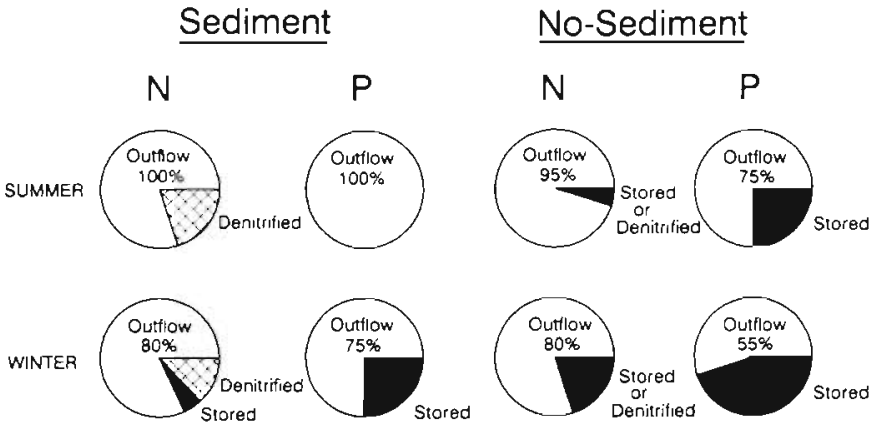

Fig. 4. Percent of total $\mathrm{N}$ or $\mathrm{P}$ inputs to control mesocosms lost in outflowing water, or retained within these treatments to be stored or denitrified. In the treatment with sediments during the summer, $100 \%$ of $\mathrm{N}$ inputs were accounted for in the water flowing from the system. An additional $20 \%$ was denitrified. This additional $\mathrm{N}$ came from decreases in water column and sediment standing stocks during the summer budget period. No measurements of denitrification were made in No-Sediment treatments and the proportion of retained nitrogen that was denitrified in these treatments is unknown tion of eutrophied treatments with and without sediment communities (Fig. 5), although there tended to be more storage of $\mathrm{N}$ and $\mathrm{P}$ in the treatments without sediments. There was also no significant difference in the percentage of $\mathrm{P}$ relative to $\mathrm{N}$ lost in outflowing water in the eutrophied treatments; however there was generally more storage of $\mathrm{P}$ than $\mathrm{N}$ due to the selective loss of $\mathrm{N}$ through denitrification.

\section{Changes in nutrient standing stocks}

Efforts were made to reconcile the amount of $\mathrm{N}$ and $\mathrm{P}$ stored in the mesocosms during the 2 budget periods with observed changes in water column and sediment nutrient standing stocks. During the summer, the net export of $\mathrm{N}$ from the control mesocosm reflected a decline in water column standing stocks. The storage of $\mathrm{N}$ and $\mathrm{P}$ in the eutrophied treatments corresponded to increases in $\mathrm{N}$ and $\mathrm{P}$ in both the water column and sediments (Table $1 \mathrm{a}, \mathrm{b}$ ).

In the sediments, changes in nutrient standing stock were based on changes in the amount of $N$ or $P$ per gram of dry sediment in the top centimeter of sediment cores taken on the day before nutrient additions to the

\section{X AND $8 X+$ SI MESOCOSMS}

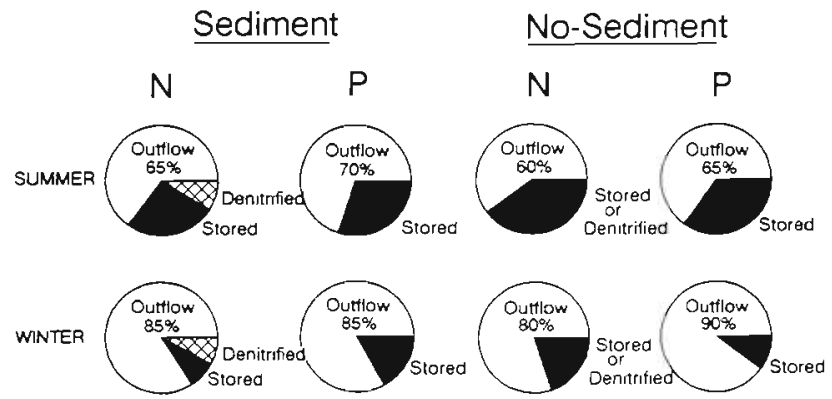

Fig. 5. Percent of total $\mathrm{N}$ or $\mathrm{P}$ inputs to the $8 \times$ and $8 x+\mathrm{Si}$ mesocosms lost in outflowing water, or retained within these treatments to be stored or denitrified eutrophied treatments began, and again at the beginning, middle, and end of each budgeting period. Results of $\mathrm{N}$ and $\mathrm{P}$ analysis showed small but, in some cases, statistically significant changes in the nutrient content of the sediments. For the $8 \times$ and $8 \times+$ Si treatments there was an increase in both $\mathrm{N}$ and $\mathrm{P}$ in the surface sediments during the summer budgeting period. Surface sediments from cores taken at the end of the summer period were significantly ( $p=0.001$ ) higher in $\mathrm{N}$ than sediments collected before the nutrient additions began or at the beginning of the summer budget period. There was also a measurable but not statistically significant increase in $P$ during this same time period.

Results for $8 \times$ and $8 x+$ Si sediments were not statistically different so these data were pooled for comparison with control sediments. At the end of the summer budget period, $8 \times$ and $8 \times+$ Si treatment sediments contained significantly more $N$ than did sediments from the control ( $p=0.025$ ), and winter cores from the nutrient treatments contained more $\mathrm{N}(\mathrm{p}=0.05)$ and more P $(p=0.001)$ than did winter cores from the control. Sediments from the control did not change measurably in their $\mathrm{N}$ or $\mathrm{P}$ content during either of the budgeting periods, although pooled winter cores from the control contained significantly more $N(p=0.01)$ than pooled summer cores.

At the beginning of the experiment, the top centimeter of sediment in each mesocosm contained ca $1800 \mathrm{mg}$-at. $\mathrm{N}$ and $350 \mathrm{mg}$-at. P per mesocosm $\left(2.5 \mathrm{~m}^{2}\right)$. Changes in sediment nutrient standing stocks were difficult to measure against this background and were further complicated by the fact that they did not occur all at once but instead were spread over the 2 mo budget periods, and were accompanied by ongoing sediment nutrient remineralization. Only the nitrogen retention observed during the summer budget period in the $8 x$ and $8 x+$ Si treatments was large enough to cause a statistically significant change in sediment $N$ standing stocks, with about half of the retained $N$ stored in the sediments (Table $1 \mathrm{a}$ ). 
Changes in sediment nutrient standing stock in the NoSediment treatments were due to the accumulation of detrital material on the bottom of the mesocosms. The amount of detrital material present on the bottom varied widely over time but did show a significant increase in all treatments over the course of the experiment (Table 3). A rapid accumulation of detrital material on the bottoms of the $8 \times$ and $8 \times+$ Si treatments relative to the control occurred primarily in the first 4 mo following the start of nutrient additions. By the end of July, a month and a half after the start of nutrient additions to the eutrophied treatments, there was twice as much material present on the bottom of the $8 \times$ and $8 x+\mathrm{Si}$ No-Sediment treatments as on the bottom of the NoSediment control (Table 3).

Not only did the quantity of material on the bottoms of the No-Sediment treatments increase over time, but the $\mathrm{N}$ and $\mathrm{P}$ content of this material increased as well. In the control the $\mathrm{N}$ and $\mathrm{P}$ content of the bottom detritus was twice as high at the end of the summer budget period as at the beginning. In the nutrient treatments the $\mathrm{N}$ and $\mathrm{P}$ content of the bottom detritus increased much more rapidly than in the control, doubling within the first month of nutrient additions (Table 3). By the end of July there was twice as much $N$ and $P$ per gram of material in the $8 \times$ and $8 \times+$ Si treatments as in the control. The average $\mathrm{C} / \mathrm{N}$ ratio (7.6) of the eutrophied detrital material was significantly lower $(p>0.001)$ and the N/P ratio (14) significantly higher than the average $\mathrm{C} / \mathrm{N}$ (11.2) and N/P (11) of detrital material from the control.

\section{DISCUSSION}

\section{Analysis of errors in the budgets}

One important outcome of these budgeting efforts was the information they provided on just how accurately terms in nutrient budgets for the mesocosms could be estimated. Budgets for these carefully controlled model systems provide insight into how well one might expect the terms in budgets for natural estuarine systems to be known.

With a flushing time for the mesocosms of $27 \mathrm{~d}$, the inflow and outflow terms were the largest values in the nutrient budgets for the controls, and second only to the inorganic nutrient addition in magnitude for the

Table 3. Description of the detrital material which accumulated on the bottom of the treatments without sediments. An estimate of the total dry weight (WT) of material present on each date is given in $\mathrm{g} \mathrm{m}^{-2}$. The $\mathrm{N}$ and $\mathrm{P}$ content of the material is given in $\mathrm{mg} \mathrm{g}^{-1}$ dry weight. The $\mathrm{C} / \mathrm{N}$ ratio (by atoms) of the material is also shown

\begin{tabular}{|c|c|c|c|c|c|c|c|c|c|c|c|c|c|}
\hline \multirow{2}{*}{\multicolumn{2}{|c|}{ Date }} & \multicolumn{4}{|c|}{ Control } & \multicolumn{4}{|c|}{$8 x$} & \multicolumn{4}{|c|}{$8 \times \pm \mathrm{Si}$} \\
\hline & & Wt & $N$ & $\mathrm{P}$ & $\mathrm{C} / \mathrm{N}$ & $W t$ & $\mathrm{~N}$ & P & $\mathrm{C} / \mathrm{N}$ & $W t$ & $\mathrm{~N}$ & $\mathrm{P}$ & $C / N$ \\
\hline Jun & 27 & 59 & 6.6 & 1.3 & 10 & 28 & 7.3 & 1.8 & 10 & 31 & 8.0 & 1.7 & 9 \\
\hline Jul & 3 & 33 & & & & 31 & & & & 43 & & & \\
\hline Jul & 10 & 51 & & & & 54 & & & & 99 & & & \\
\hline Jul & 17 & 31 & 6.9 & 1.6 & 14 & 67 & 15.1 & 2.7 & 8 & 40 & 17.2 & 3.1 & 8 \\
\hline Jul & 24 & 17 & & & & 19 & & & & 83 & & & \\
\hline Jul & 31 & 52 & 9.3 & 1.7 & 12 & 156 & 20.2 & 3.4 & 9 & 103 & 21.8 & 3.4 & 8 \\
\hline Aug & 7 & 72 & & & & 100 & & & & 170 & & & \\
\hline Aug & 14 & 84 & & & & 132 & & & & 217 & & & \\
\hline Aug & 21 & 83 & & & & 339 & & & & 137 & & & \\
\hline Aug & 28 & 51 & & & & 155 & & & & 385 & & & \\
\hline Sep & 5 & 64 & & & & 245 & & & & 301 & & & \\
\hline Sep & 12 & 95 & & & & 137 & & & & 274 & & & \\
\hline Sep & 19 & 110 & 13.7 & 2.6 & 10 & 197 & 36.7 & 4.1 & 6 & 141 & 18.2 & 2.7 & 8 \\
\hline Sep & 26 & 62 & & & & 328 & & & & 392 & & & \\
\hline Oct & 17 & 270 & & & & 409 & & & & 440 & & & \\
\hline Oct & 31 & 100 & & & & 358 & & & & 204 & & & \\
\hline Dec & 9 & 65 & 12.3 & 2.3 & 10 & 119 & 26.0 & 4.7 & 8 & 718 & 22.6 & 2.9 & 7 \\
\hline Jan & 24 & 113 & 14.2 & 2.6 & 11 & 266 & 30.0 & 5.0 & 7 & 340 & 22.2 & 3.7 & 8 \\
\hline Mar & 13 & 452 & 12.1 & 2.7 & 11 & 230 & 27.9 & 4.3 & 7 & 585 & 21.7 & 4.0 & 8 \\
\hline Apr & 17 & 347 & & & & 276 & & & & 582 & & & \\
\hline May & 28 & 426 & & & & 411 & & & & 606 & & & \\
\hline Jun & 11 & 293 & & & & 191 & & & & 740 & & & \\
\hline
\end{tabular}


eutrophied treatments. The error in inflow and outflow terms was due almost entirely to variation in the volume of Bay water flow to the mesocosms, which could be well described. A comparison of the inflow and outflow terms alone leads to the conclusion that most of the nutrient input was accounted for in the outflow from the treatments.

Processes occurring within the mesocosms, such as changes in sediment and water column standing stocks and denitrification, were difficult to measure with certainty. These processes occurred on time scales that did not lend themselves to being arbitrarily sectioned into $62 \mathrm{~d}$ budget periods, and were often small in magnitude relative to the inflow and outflow terms and the inorganic nutrient addition. Obtaining realistic estimates of the net accumulation of material on the bottom of the No-Sediment treatments was difficult because the amount present varied widely over time, and because it was difficult to measure the accumulation accurately. The calculated (by difference) retention of $\mathrm{N}$ and $\mathrm{P}$ in the No-Sediment treatments corresponded only roughly to the observed accumulation of detritus on the treatment bottoms, particularly during the winter period.

There was generally more input of $\mathrm{N}$ and $\mathrm{P}$ to the mesocosms than was accounted for by loss terms in the budgets, particularly in the eutrophied treatments. Approximately 5 to $10 \%$ of the $\mathrm{N}$ and $\mathrm{P}$ available to the mesocosms in summer and $20 \%$ in winter was not accounted for in the outflowing water, or in standing stock increases or denitrification losses (Table 1a to d). While some of this discrepancy is due to the large errors involved in estimating changes in standing stocks and sediment storage, it also suggests that there were additional nutrient losses not accounted for in the nutrient budgets. The fact that this discrepancy was found in both the $\mathrm{N}$ and $\mathrm{P}$ budgets, with an average $\mathrm{N}$ :P ratio for the missing material of $12: 1$, suggests that a storage of organic material within the mesocosms was unaccounted for. One possibility is that this unaccounted for $\mathrm{N}$ and $\mathrm{P}$ was lost to a build-up of fouling communities on the mesocosm walls. Although the walls of these systems were brushed weekly to remove fouling, some growth of tunicates and other fouling organisms was observed, particularly in the region close to the mesocosm bottoms. In addition, water samples from the mesocosms tended to exclude the larger zooplankton and small fish (capable of swimming away from the bottle mouth), and thus may have missed increases in biomass of Jarger individuals in the water column.

While other terms were based on observations made on a daily or weekly basis, the estimates of denitrification were based on measurements of $\mathrm{N}_{2}$ flux from cores taken on only a few occasions (Table 2). While results for replicate cores suggest that the sediments in each mesocosm were fairly homogeneous with respect to rates of denitrification, it is difficult to know how much these rates varied during the course of the budget periods. Estimates of $\mathrm{N}$ loss through denitrification do not affect estimates of $\mathrm{N}$ export from the mesocosms in the outflowing water, but do alter the estimate of the amount of $N$ ultimately remaining in the system. In this sense the mass balances themselves provide an upper limit to the amount of $N$ remaining in these systems that was available for denitrification.

\section{Mesocosms as nutrient traps}

Regardless of treatment or season the mesocosms exported most of the nutrients that they received. Very little $\mathrm{N}$ or $\mathrm{P}$ remained trapped within these systems. The nutrient transformation processes which occurred within the mesocosms are the subject of a second paper (Nowicki unpubl.); however one important point is worth noting here. Although most of the total $\mathrm{N}$ and $\mathrm{P}$ input to the mesocosms was accounted for in the export from these systems, nutrients did not simply pass through the mesocosms unchanged. Much of the inorganic $N$ and $P$ input to the mesocosms was transformed for export in dissolved organic and particulate form (Nowicki 1990).

The budgets showed that both control treatments stored more $N$ and $P$ in winter than in summer. In addition, winter cores from the control with sediments contained significantly more $\mathrm{N}$ than summer cores. In the control without sediments, more detritus, of higher $\mathrm{N}$ and $\mathrm{P}$ content, accumulated on the bottom during winter than during summer. This seasonal storage of nutrients has been observed in natural systems and has been attributed to a lack of benthic remineralization of nutrients at low winter temperatures (Nixon 1981). The winter storage and subsequent summer release of nutrients from sediments may be responsible for the characteristic annual cycles of nutrients observed in many estuaries, as well as in these control mesocosms, and for summer peaks in phytoplankton production observed in systems such as Narragansett Bay and Chesapeake Bay (Nixon \& Pilson 1983, Kemp \& Boynton 1984, Pilson 1985a, Malone et al. 1988).

\section{Role of sediments}

In general the treatments without sediments retained more $\mathrm{N}$ and $\mathrm{P}$ than did their sedimented counterparts. This additional $\mathrm{N}$ and $\mathrm{P}$ appears to have accumulated primarily in the flocculent material on the bottom. The presence of an intact sediment community increased the $N$ export from the mesocosms by $5 \%$ and increased 
$\mathrm{P}$ export by 5 to $25 \%$, perhaps by increasing the exchange of nutrients with the overlying water column and by decreasing sediment nutrient storage. Benthic flux data for treatments with and without sediments suggest that, at least in the controls, nutrient fluxes were considerably higher in the treatments with sediments than in their No-Sediment replicates (Doering et al. 1989).

An interesting result of the budgeting efforts was the apparent retention of $P$ relative to $N$. In the treatments with sediments this was primarily due to the selective loss of $N$ through denitrification. In the control without sediments however, the selective retention of $\mathrm{P}$ reflects an actual loss of $\mathrm{N}$ relative to $\mathrm{P}$ in the flow from the mesocosm during both seasons. It is interesting to note that benthic fluxes of inorganic $P$ were negative (into the sediments) during both budget periods for this treatment (Doering et al. 1989).

\section{Impact of eutrophication}

The daily addition of substantial amounts of inorganic $N$ and $P$ to the $8 x$ and $8 x+$ Si treatments initially caused large increases in water column and sediment nutrient standing stocks. However winter mass balances for these treatments, prepared after 6 mo of daily nutrient loading, showed that they retained only 5 to $10 \%$ of the $\mathrm{N}$ and 10 to $15 \%$ of the $\mathrm{P}$ added to them. Because of the large nutrient addition to these treatments the actual amount of $\mathrm{N}$ and $\mathrm{P}$ retained was 10 times the amount of $\mathrm{N}$ and 2 to 5 times the $\mathrm{P}$ retained by the control mesocosms for the same time period. The added nutrients resulted in increases in the $N$ and $P$ content of surface sediments in the treatments with sediments, and the rapid deposition of a nutrient-rich detrital layer in the treatments without sediments. The large and rapid accumulation of detrital material on the bottoms of the eutrophied No-Sediment treatments appears to have served the biogeochemical function of an intact benthos by remineralizing nutrients to the overlying water column (Doering et al. 1989). This tended to obscure differences between eutrophied treatments with and without sediments, and effects that might have been attributed to the lack of a sediment community.

One consequence of the increased input of highnutrient organic material to the bottoms of the $8 x$ and $8 x+$ Si treatments was an increase in rates of sediment denitrification. Denitrification rates were twice as high in the $8 x$ and $8 x+$ Si treatments as in the control, and represented a loss of about $10 \%$ of the $\mathrm{N}$ added to the nutrient-treated mesocosms

\section{Atmospheric contributions}

Observed rates of wet deposition of $\mathrm{N}$ and $\mathrm{P}$ were similar to those reported in other studies in the northeastern USA and North Atlantic regions (Table 4). The influence of anthropogenic contaminants from the continental USA is clear when comparing observed values with those reported for the Sargasso Sea or Bermuda. Few measurements of atmospheric dry deposition of nutrients are currently available in the literature. In most cases dryfall estimates have been based on models of particle deposition velocities which may be subject to considerable uncertainty (Duce 1986) and few empirical measurements of nutrient dryfall exist. Dryfall estimates in this study were based on direct measurements of deposition to a seawater surface; however measurements were made on only 4 occasions and hence give no information about the seasonality of this nutrient source. Preliminary results suggest however that dryfall may be as important as wetfall as a nutrient source to coastal systems and will need to be included in future budgeting efforts.

If the observed atmospheric inputs for the 2 budget periods are extrapolated on an annual basis to Narragansett Bay, then wet deposition might account for 5 to $10 \%$ of the total $N$ and $5 \%$ of the total $P$ input to the Bay annually (Nixon 1981, Nixon \& Pilson 1983). These estimates are similar to those of Smullen et al. (1982) who found that wet deposition accounted for $13 \%$ of $\mathrm{N}$ and $5 \%$ of $P$ inputs to the Chesapeake Bay annually.

\section{Nutrient export from natural systems}

For the experiments described in this study the mesocosms were maintained as well-mixed systems with an average salinity of $29 \%$. As such they served as analogs for the seaward reaches of estuaries such as lower Narragansett Bay or lower Chesapeake Bay, where the exchange of saltwater at the estuary mouth maintains the lower estuary as an open, non-stratified basin of fairly high salinity. Nutrient trapping processes which occur in the salinity gradients of upper estuaries, or particle trapping due to stratification or to 2-layer estuarine circulation would not be expected in this type of system. Instead, nutrient trapping would occur primarily as a result of primary production and the delivery of particulate material to the bottom sediments. Results of this study showed that these nonstratified, high salinity systems were not effective nutrient traps for either nitrogen or phosphorus. Both control systems and those receiving large anthropogenic nutrient additions ultimately exported most of the $\mathrm{N}$ and $\mathrm{P}$ that they received.

Most nutrient budgets available to date for natural 
Table 4. Nutrients in wet and dry deposition for the eastern USA. Units are mmol $\mathrm{m}^{-2} \mathrm{yr}^{-1}$

\begin{tabular}{|c|c|c|c|c|}
\hline Study & Region & Species & Wet deposition & Dry deposition \\
\hline Galloway \& Whelpdale (1987) & $\begin{array}{l}\text { Western } \\
\text { North Atlantic }\end{array}$ & $\begin{array}{l}\mathrm{NO}_{3} \\
\mathrm{NO}_{4}, \mathrm{HNO}_{3}, \mathrm{NO}_{3}\end{array}$ & $9 \pm 30 \%$ & $16 \pm 100 \%$ \\
\hline Duce (1986) & $\begin{array}{l}\text { Sargasso } \\
\text { Sea }\end{array}$ & $\begin{array}{l}\mathrm{NO}_{3} \\
\mathrm{NH}_{4} \\
\mathrm{HNO}_{3} \\
\mathrm{PO}_{4}\end{array}$ & $\begin{array}{l}4-7 \\
4-6\end{array}$ & $\begin{array}{l}2-6 \\
0.1-0.4 \\
0.2-0.7 \\
0.04-0.1\end{array}$ \\
\hline Knap et al. (1986) & Bermuda & $\begin{array}{l}\mathrm{NO}_{3} \\
\mathrm{NH}_{4} \\
\mathrm{DON}\end{array}$ & $\begin{array}{r}6 \\
5 \\
11\end{array}$ & \\
\hline Likens et al. (1977) & $\begin{array}{l}\text { Hubbard Brook, } \\
\text { New Hampshire } \\
\text { (10 yr mean) }\end{array}$ & $\begin{array}{l}\mathrm{NO}_{3} \\
\mathrm{NH}_{4} \\
\mathrm{PO}_{4}\end{array}$ & $\begin{array}{l}32 \pm 3.4 \\
16 \pm 1 \\
0.14\end{array}$ & \\
\hline Kortmann (1980) & $\begin{array}{l}\text { Dunham Pond, } \\
\text { Mansfield, } \\
\text { Connecticut }\end{array}$ & $\begin{array}{l}\mathrm{NO}_{3} \\
\mathrm{NH}_{4} \\
\mathrm{DON} \\
\mathrm{TP}\end{array}$ & $\begin{array}{r}23 \\
18 \\
28 \\
4\end{array}$ & \\
\hline Barrie \& Hales (1984) & $\begin{array}{l}\text { Northeast } \\
\text { USA } \\
\text { (for 1980) }\end{array}$ & $\begin{array}{l}\mathrm{NO}_{3} \\
\mathrm{NH}_{4}\end{array}$ & $\begin{array}{r}20-30 \\
0-20\end{array}$ & \\
\hline Eshleman \& Hemond (1988) & $\begin{array}{l}\text { Central } \\
\text { Massachusetts } \\
\text { (2 yr mean) }\end{array}$ & $\mathrm{NO}_{3}$ & 30 & \\
\hline This study & $\begin{array}{l}\text { Narragansett, } \\
\text { Rhode Island }\end{array}$ & $\mathrm{NO}_{3}$ & $\begin{array}{ll}70 & (\mathrm{~S}) \\
20 & (\mathrm{~W})\end{array}$ & 15 \\
\hline \multirow[t]{3}{*}{$\begin{array}{l}\text { ( } S=\text { based on summer values }) \\
(W=\text { based on winter values })\end{array}$} & & $\mathrm{NH}_{4}$ & $\begin{aligned} 45 & (\mathrm{~S}) \\
8 & (\mathrm{~W})\end{aligned}$ & 40 \\
\hline & & DON & $10(W)$ & \\
\hline & & $\mathrm{PO}_{4}$ & $\begin{array}{l}0.3(\mathrm{~S}) \\
0.1(\mathrm{~W})\end{array}$ & 5 \\
\hline
\end{tabular}

estuarine systems are incomplete, generally lacking a term for the exchange of nutrients with offshore waters. At present, the most comprehensive $\mathrm{N}$ budget available for Narragansett Bay (Nixon \& Pilson 1983) lacks a term for offshore exchange. The $\mathrm{N}$ budgets described in this study for the control mesocosm (when winter and summer results are averaged to provide annual estimates) agree closely with the Bay budget, and suggest an export of total $\mathrm{N}$ to offshore waters on the order of $4 \mathrm{mmol} \mathrm{N} \mathrm{m}^{-2} \mathrm{~d}^{-1}$ (Table 5). It is also interesting to note that the water flowing into the mesocosms from lower Narragansett Bay contained $N$ equal to $75 \%$ of the total $\mathrm{N}$ input to the Upper Bay from runoff, rivers, and sewage (Table 5). This suggests that most of the $\mathrm{N}$ found in anthropogenic inputs to Upper Narragansett Bay is still present at a location close to the Bay mouth.

Recent studies of a number of estuaries suggest that they may export a large proportion of the nutrients that they receive annually (Table 6). The fact that many estuaries may not effectively trap or filter most of the nutrients that they receive has important consequences for primary production in the world's oceans, particularly as inputs of anthropogenic nutrients to coastal areas increase. In a survey of 60 of the world's largest rivers, Meybeck (1982) concluded that man's activities in recent years have doubled the world's riverine $\mathrm{P}$ load and increased the total dissolved $\mathrm{N}$ load by 30 to $50 \%$. In some locations, river water $N$ and $\mathrm{P}$ concentrations have increased by a factor of 50 or more. In assessing the impact that these additional nutrient loads might have on the world oceans, Meybeck concluded that 'The net flux of nutrients to the oceans is difficult to estimate because of their high reactivity in the estuarine and coastal zones: phytoplankton uptake, change of chemical speciations from the soluble forms to the gaseous ones $\left(\mathrm{CO}_{2}, \mathrm{~N}_{2}, \mathrm{~N}_{2} \mathrm{O}\right)$, and flocculation of particulate matter... For all these reasons it is not possible to state exactly the behavior of all nutrient speciations at the ocean-continent interface nor quantify the resulting fluxes.' Results reported here of nutrient budgets for estuarine mesocosms suggest that 
Table 5. Comparison of a comprehensive N budget for Narragansett Bay and results from this study. ND: non-detectable

\begin{tabular}{|c|c|c|c|}
\hline & \multicolumn{3}{|c|}{ Total $N\left(\mu \mathrm{mol} \mathrm{m}{ }^{-2} \mathrm{~d}^{-1}\right)$} \\
\hline & \multicolumn{2}{|c|}{$\begin{array}{c}\text { Narragansett } \\
\text { Bay }^{a}\end{array}$} & $\begin{array}{c}\text { Control } \\
\text { mesocosm }\end{array}$ \\
\hline \multicolumn{4}{|l|}{ Sources } \\
\hline Fixation & & $<2$ & $?$ \\
\hline Precipitation & & 148 & 399 \\
\hline Runoff & & 165 & \\
\hline Groundwater & & $?$ & \\
\hline Rivers & & 2438 & -4109 \\
\hline Sewage & & 2885 & \\
\hline \multirow[t]{2}{*}{ Offshore } & & $?$ & \\
\hline & Total & $>\overline{5638}$ & $\overline{4508}$ \\
\hline \multicolumn{4}{|l|}{ Sinks } \\
\hline Sedimentation & & 361 & ND \\
\hline Denitrification & & 1411 & 880 \\
\hline Fisheries & & $<14$ & 0 \\
\hline Offshore & & $?$ & 4339 \\
\hline & Total & $>\longdiv { 1 7 8 6 }$ & $\overline{5219}$ \\
\hline \multicolumn{4}{|c|}{ ¿ Nixon \& Pilson (1983) } \\
\hline
\end{tabular}

most of the nitrogen and phosphorus input to wellmixed estuarine systems may be exported to offshore waters. Locally, the annual inorganic $N$ input from rivers and sewage to Narragansett Bay of $950 \mathrm{mg}$-at. $\mathrm{N}$ $\mathrm{m}^{-2} \mathrm{yr}^{-1}$ (Nixon \& Pilson 1983), if exported offshore, could support $25 \%$ of the $300 \mathrm{~g} \mathrm{C} \mathrm{m}^{-2} \mathrm{yr}^{-1}$ annual primary production in Rhode Island Sound (Sherman et al. 1988), if used only once, or $100 \%$ of this production if recycled 4 or 5 times annually. On a global scale, the world's annual riverine nutrient load of $43 \mathrm{Tg} \mathrm{N}$ and 22 Tg P (Meybeck 1982, Berner \& Berner 1987), if converted to organic matter (106.16:1 C:N:P), could add an additional $50 \mathrm{~g} \mathrm{C} \mathrm{m}^{-2} \mathrm{yr}^{-1}$ (if recycled 5 times) to rates of production on the world's continental shelves averaging 100 to $400 \mathrm{~g} \mathrm{C} \mathrm{m}^{-2} \mathrm{yr}^{-1}$ (Cushing 1988).

Acknowledgements. We thank other members of the MERL staff for their hard work and dedication, particularly P. Doering, whose patience and organizational skills made this experiment possible. E. Klos and E. Requintina maintained the carefully controlled flow, temperature, and mixing regimes essential to the mesocosms and provided invaluable mechanical and engineering wizardry. N. Craig helped with sediment coring, and N. Craig, E. Klos, and K. Asjian sampled the detrital material on the bottoms of the No-Sediment treatments. This work was supported by EPA Grant CR 812487-01-1.

\section{LITERATURE CITED}

Barrie, L. A., Hales, J. M. (1984). The spatial distributions of precipitation acidity and major ion wet deposition in North America during 1980. Tellus 36B: 333-355

Beach, R. B. (1981). Phosphorus uptake and release by sediments from Narragansett Bay. M.S. thesis, Univ. Rhode Island, Kingston

Berner, E. K., Berner, R. A. (1987). The global water cycle. Prentice-Hall, Inc, New Jersey, p. 227-240

Biggs, R. B., Howell, B. A. (1984). The estuary as a sediment trap: alternate approaches to estimating its filtering efficiency. In: Kennedy, V S. (ed.) The estuary as a filter. Academic Press, New York, p. 107-129

Table 6. Percent of total nutrient inputs exported to offshore waters by a number of natural estuarine systems

\begin{tabular}{|c|c|c|c|c|c|}
\hline Study & Site & Method & $\mathrm{N}$ & $P$ & $\mathrm{Si}$ \\
\hline $\begin{array}{l}\text { Loder \& Glibert } \\
\text { (1980) }\end{array}$ & $\begin{array}{l}\text { Great Bay, } \\
\text { New Hampshire }\end{array}$ & Conservative mixing & - & $\begin{array}{l}12 \% \\
(\mathrm{DIP})\end{array}$ & - \\
\hline Smith (1981) & Kaneohe Bay, Hawaii & Mass balance & $\begin{array}{l}100 \% \\
(\mathrm{DIN})\end{array}$ & - & - \\
\hline $\begin{array}{l}\text { Smullen et al. } \\
(1982)\end{array}$ & Chesapeake Bay & Mass balance & $24 \%$ & $19 \%$ & - \\
\hline D'Elia et al. (1983) & Chesapeake Bay & Mass balance & - & - & $0-40 \%$ \\
\hline $\begin{array}{l}\text { Kaul \& Froelich } \\
\text { (1984) }\end{array}$ & $\begin{array}{l}\text { Ochlockonee Bay, } \\
\text { Florida }\end{array}$ & Conservative mixing & $80 \%\left(\mathrm{NO}_{2}+3\right)$ & $\begin{array}{l}98 \% \\
\text { (DIP) }\end{array}$ & $99 \%$ \\
\hline Nixon et al. (1986) & Narragansett Bay & Sediment analysis & $95 \%$ & $95 \%$ & - \\
\hline Nixon (1987) & Chesapeake Bay & Sediment analysis & $94-97 \%$ & $83-89 \%$ & $17-67 \%$ \\
\hline Fisher et al. (1988) & Chesapeake Bay & Conservative mixing & $29-67 \%$ & $100 \%$ & $1-60 \%$ \\
\hline Fisher et al. (1988) & Delaware Bay & Conservative mixing & $46-60 \%$ & $38-57 \%$ & $8->100 \%$ \\
\hline $\begin{array}{l}\text { Meybeck et al. } \\
\text { (1988) }\end{array}$ & Loire Estuary, France & Conservative mixing & $\begin{array}{l}>100 \% \\
\text { (DIN) }\end{array}$ & $\begin{array}{l}>100 \% \\
\text { (DIP) }\end{array}$ & $90 \%$ \\
\hline $\begin{array}{l}\text { This study } \\
\text { (Control with se }\end{array}$ & $\begin{array}{l}\text { Rhode Island } \\
\text { ments) }\end{array}$ & Mass balance & $80-100 \%$ & $75-100$ & - \\
\hline
\end{tabular}


Boon, J. D., III. (1978). Suspended solids transport in a salt marsh creek - an analysis of errors. In: Kjerfve, B. (ed.) Estuarine transport processes. Univ. South Carolina Press, Columbia, p. 147-159

Cushing, D. H. (1988). The flow of energy in marine ecosystems, with special reference to the continental shelf. In: Postma, H., Zijlstra, J. J. (eds.) Ecosystems of the world, Vol. 27 Continental shelves. Elsevier, Amsterdam, p. $203-230$

D'Elia, C. F., Nelson, D. M., Boynton, W. R. (1983). Chesapeake Bay nutrient and plankton dynamics: III. The annual cycle of dissolved silicon. Geochim. cosmochim. Acta 47: 1945-1955

Doering, P. H. (1989). On the contribution of the benthos to pelagic production. J. mar. Res. 47: 371-383

Doering, P. H., Oviatt, C. A., Beatty, L. L., Banzon, V. F., Rice, R., Kelly, S. P., Sullivan, B. K., Frithsen, J. B. (1989). Structure and function in a model coastal ecosystem: silicon, the benthos and eutrophication. Mar. Ecol. Prog. Ser. 52: $287-299$

Duce, R. A. (1986). The impact of atmospheric nitrogen, phosphorus, and iron species on marine biological productivity. In: Buat-Menard, P. (ed.) The role of air-sea exchange in geochemical cycling. Reidel, Dordrecht, p. 497-529

Dunstan, W. M., Atkinson, L. P. (1976). Sources of new nitrogen for the South Atlantic Bight. In: Wiley; M. (ed.) Estuarine processes, Vol. 1. Academic Press, New York, p. 69-78

Elmgren, R., Frithsen, J. B. (1982). The use of experimental ecosystems for evaluating the environmental impact of pollutants: a comparison of an oil spill in the Baltic Sea and two long-term, low-level oil addition experiments in mesocosms. In: Grice, G. D., Reeve, M. R. (eds.) Marine mesocosms: biological and chemical research in experimental ecosystems. Springer-Verlag, New York, p. 153-165

Eshleman, K. N., Hemond, H. F. (1988). Alkalinity and major ion budgets for a Massachusetts reservoir and watershed. Limnol. Oceanogr. 33 (2): 174-185

Fisher, T R., Harding, L. W., Jr, Stanley, D. W., Ward, L. G. (1988). Phytoplankton, nutrients and turbidity in the Chesapeake, Delaware, and Hudson estuaries. Estuar. coast. Shelf Sci. 27:61-93

Froelich, P. N., Bender, M. L., Leudtke, N. A., Heath, G. R., DeVries, T. (1982). The marine phosphorus cycle. Am. J. Sci. 282: 474-511

Galloway, J. N., Whelpdale, D. M. (1987). WATOX-86 overview and western, North Atlantic Ocean $\mathrm{S}$ and $\mathrm{N}$ atmospheric budgets. Global biogeochem. Cycles 1(4): 261-281

Haines, E. B. (1975). Nutrient inputs to the coastal zone: the Georgia and South Carolina Shelf. In: Cronin, L. E. (ed.) Estuarine research, Vol. 1. Academic Press, New York, p. $303-324$

Hedgpeth, J. W. (1967). The sense of the meeting. In: Lauft, G. (ed.) Estuaries. Publs Am. Ass. Advmt Sci. No. 83, p. $707-710$

Hobbie, J. E., Copeland, B. J., Harrison, W. G. (1975). Sources and fates of nutrients of the Pamilico River Estuary, North Carolina. In: Cronin, L. E. (ed.) Estuarine research, Vol. 1. Academic Press, New York, p. 287-302

Hoffman, E. J., Quinn, J. G. (1984). Hydrocarbons and other pollutants in urban runoff and combined sewer overflows. A report submitted to NOAA Oceans Assessments Division, Grant NA80RAD00047, Washington, D. C.

Hopkinson, C. S., Jr, Hoffman, F. A. (1984). The estuary extended - a recipient-system study of estuarine outwelling in Georgia. In: Kennedy, V S. (ed.) The estuary as a filter. Academic Press, New York, p. 313-330
Hunt, C. D., Smith, D. L. (1982). Controlled marine ecosystems - a tool for studying stable trace metal cycles: Long-term response and variability. In: Grice, G. D., Reeve, M. R. (eds.) Marine mesocosms: biological and chemical research in experimental ecosystems. Springer-Verlag. New York, p. 111-122

Jaworski, N. A. (1981). Sources of nutrients and the scale of eutrophication problems in estuaries. In: Neilson, B. J., Cronin, L. E. (eds.) Estuaries and nutrients. Humana Press, Clifton, N.J., p. 83-110

Kaul, L. W., Froelich, P. N., Jr, (1984). Modeling estuarine nutrient geochemistry in a simple system. Geochim. cosmochim. Acta 48: 1417-1433

Keller, A. A. (1988). An empirical model of primary productivity $\left({ }^{14} \mathrm{C}\right)$ using mesocosm data along a nutrient gradient. J. Plankton Res. 10: 813-834

Kemp, W. M., Boynton, W R. (1984). Spatial and temporal coupling of nutrient inputs to estuarine primary production: the role of particulate transport and decomposition. Bull. mar. Sci. 35: 242-247

Ketchum, B. H. (1967). Phytoplankton nutrients in estuaries. In: Lauff, G. (ed.) Estuaries. Publs Am. Ass. Advmt Sci. No. 83, p. 329-335

Kjerfve, B., Proehl, J. A., Schwing, F. B., Seim, H. E., Marozas, M. (1982). Temporal and spatial considerations in measuring estuarine water fluxes. In: Kennedy, V. S. (ed.) Estuarine comparisons. Academic Press, New York, p. $37-51$

Knap, A., Jickells, T., Pszenny, A., Galloway, J. (1986). Significance of atmospheric-derived fixed nitrogen on productivity of the Sargasso Sea. Nature, Lond. 320: 158-160

Kortmann, R. W. (1980). Benthic and atmospheric contributions to the nutrient budgets of a soft-water lake. Limnol. Oceanogr 25 (2): 229-239

Lambert, C. E., Oviatt, C. A. (eds.) (1986). Manual of biological and geochemical techniques in coastal areas. MERL Series, Report No. 1, 2nd edn. The University of Rhode Island, Kingston

Likens, G. E., Bormann, F. H., Pierce, R. S., Eaton, J. S., Johnson, N. M. (1977). Biogeochemistry of a forested ecosystem. Springer-Verlag, New York

Loder, T C., Glibert, P. M. (1980). Nutrient variability and fluxes in an estuarine system. In: Kennedy, $V$ S. (ed.) Estuarine perspectives. Academic Press, New York. p. $111-122$

Malone, $T$ C. (1984). Anthropogenic nitrogen loading and assimilation capacity of the Hudson River Estuarine System, USA. In: Kennedy, V S. (ed.) The estuary as a filter. Academic Press, New York, p. 291-311

Malone, T C., Crocker, L. H., Pike, S. E., Wendler, B. W. (1988). Influences of river flow on the dynamics of phytoplankton production in a partially stratified estuary. Mar. Ecol. Prog. Ser. 48: 235-249

Mansueti, R. J. (1961). Effects of civilization on striped bass and other estuarine biota in Chesapeake Bay and tributaries. Proc. Gulf Caribb. Fish. Inst., p. 110-136

Meybeck, M. (1982). Carbon, nitrogen, and phosphorus transport by world rivers. Am. J. Sci. 282: 401-450

Meybeck, M., Cauwet, G., Dessery, S., Somville, M., Gouleau, D., Billen, C. (1988). Nutrients (organic C, P, N, Si) in the eutrophic river Loire (France) and its estuary. Estuar. coast. Shelf Sci. 27: 595-624

Nixon, S. W. (1981). Remineralization and nutrient cycling in coastal marine ecosystems. In: Neilson, B. J., Cronin, L. E. (eds.) Estuaries and nutrients. Humana Press, Clifton, N.J., p. $111-138$ 
Nixon, S. W. (1983). Estuarine ecology - a comparative and experimental analysis using 14 estuaries and the MERL microcosms. Final report to the U.S. Environmental Protection Agency, Chesapeake Bay Program, Washington, D. C.

Nixon, S. W., Furnas, B. N., Chinman, R., Granger, S., Heffernan, S. (1982). Nutrient inputs to Rhode Island coastal lagoons and salt ponds. Final report to Rhode Island Statewide Planning, Providence, Rhode Island

Nixon, S. W. Pilson, M. E. Q. (1983). Nitrogen in estuarine and coastal marine ecosystems. In: Carpenter, E. J., Capone, D. G. (eds.) Nitrogen in the marine environment. Academic Press, New York, p. 565-648

Nixon, S. W., Pilson, M. E. Q. (1984). Estuarine total system metabolism and organic exchange calculated from nutrient ratios: an example from Narragansett Bay. In: Kennedy, V. S. (ed.) The estuary as a filter. Academic Press, New York, p. 261-290

Nixon, S. W., Hunt, C. D., Nowicki, B. L. (1986). The retention of nutrients $(\mathrm{C}, \mathrm{N}, \mathrm{P})$, heavy metals $(\mathrm{Mn}, \mathrm{Cd}, \mathrm{Pb}, \mathrm{Cu})$, and petroleum hydrocarbons in Narragansett Bay. In: Lasserre, P., Martin, J. M. (eds.) Biogeochemical processes at the land-sea boundary. Elsevier Press, New York, p. 99-122

Nixon, S. W (1987). Chesapeake Bay nutrient budgets - a reassessment. Biogeochem. 4: 77-90

Nowicki, B. L. (1990). Estuaries as nutrient traps and transformers: evidence from mesocosm experiments. Ph.D. thesis, University of Rhode Island, Graduate School of Oceanography, Kingston

Odum, E. P. (1971). Fundamentals of Ecology, 3rd. edn. W. B. Saunders Co., Philadelphia

Oviatt, C. A., Buckley, B., Nixon, S. (1981). Annual phytoplankton metabolism in Narragansett Bay calculated from survey field measurements and microcosm observations. Estuaries 4 (3): 167-175

Peterson, D. H. (1979). Sources and sinks of biologically reactive oxygen, carbon, nitrogen, and silica in Northern San Francisco Bay. In: Conomos, T. J. (ed.) San Francisco Bay: the urbanized estuary. Pacific Division, Am. Ass. Advance. Sci., San Francisco, p. 175-193

Peterson, D. H., Conomos, T. J., Broenkow, W. W., Scrivani, E. P. (1975). Processes controlling the dissolved silica distributions in San Francisco Bay. In: Cronin, L. E. (ed.) Estuarine research, Vol. 1. Academic Press, New York, p. 153-187

Pilson, M. E. Q. (1985a). Annual cycles of nutrients and chlorophyll in Narragansett Bay, Rhode Island. J. mar. Res. 43: 849-873

Pilson, M. E. Q. (1985b). On the residence time of water in Narragansett Bay. Estuaries 8 (1): 2-14

Pilson, M. E. Q. Oviatt, C. A., Vargo, G. A., Vargo, S. L. (1979). Replicability of MERL microcosms: initial observations. In: Jacoff, F. S. (ed.) Advances of marine environmental research. Report EPA-600/9-79-035,

This article was submitted to the editor
Environmental Protection Agency, Narragansett, p. $359-381$

Pilson, M. E. Q., Oviatt, C. A., Nixon, S. W (1980). Annual nutrient cycles in a marine microcosm. In: Giesy, J. P. (ed.) Microcosms in ecological research. DOE Symposium Series, Augusta, Georgia, Nov. 8-10, 1978. CONF 7811-1 NTIS, p. 753-778

Pritchard, D. W. (1955). Estuarine circulation patterns. Proc. Am. Soc. Civ. Engrs 81 (717): 1-11

Ramette, R. W. (1981). Chemical equilibrium and analysis. Addison-Wesley Publishing Co., Reading, Mass.

Riley, G. A. (1967). Mathematical model of nutrient conditions in coastal waters. Bull. Bingham oceanogr. Coll. 19: 72-80

Santschi, P. H. (1982). Application of enclosures to the study of ocean chemistry. In: Grice, G. D., Reeve, M. R. (eds.) Marine mesocosms: biological and chemical research in experimental ecosystems. Springer-Verlag, New York, p. 63-80

Schelske, C. L., Odum, E. P. (1961). Mechanisms maintaining high productivity in Georgia estuaries. Proc. Gulf Caribb Fish. Inst. 14: 75-80

Schubel, J. R., Kennedy, V S. (1984). The estuary as a filter: an introduction. In: Kennedy, V S. (ed.) The estuary as a filter, Academic Press, New York, p. 1-11

Seitzinger, S. P. Nixon, S. W., Pilson, M. E. Q. (1984). Dentrification and nitrous oxide production in a coastal marine ecosystem. Limnol. Oceanogr. 29 (1): 73-83

Sherman, K., Grosslein, M., Mountain, D., Busch, D., O'Reilly, J., Theroux, R. (1988). The continental shelf ecosystem of the Northeast coast of the United States. In: Postma, H. Zijlstra, J. J. (eds.) Ecosystems of the world, Vol. 27, Continental shelves. Elsevier, Amsterdam, p. 279-337

Sholkovitz, E. (1976). Flocculation of dissolved organic and inorganic matter during the mixing of river water and seawater. Geochim. cosmochim. Acta 40: 831-845

Smith, S. V (1981). Responses of Kaneohe Bay, Hawaii to relaxation of sewage stress. In: Neilson, B. J., Cronin, L. E. (eds.) Estuaries and nutrients. Humana Press, Clifton, N.J., p. $391-410$

Smullen, J. T., Taft, J., Macknis, J. (1982). Nutrient and sediment loads to the tidal Chesapeake Bay system. In: Macalaster, E. G., Barker, D. A., Kasper, M. (eds.) Chesapeake Bay Program technical studies: a synthesis. U.S. Environmental Protection Agency, Washington, D.C., p. $147-262$

Valderrama, J. C. (1981). The simultaneous analysis of total nitrogen and total phosphorus in natural waters. Mar Chem. 10: 109-122

Wakeham, S. G., Davis, A. C., Goodwin, J. T (1982). Biogeochemistry of volitile organic compounds in marine experimental ecosystems and the estuarine environment - initial results. In: Grice, G. D., Reeve, M. R. (eds.) Marine mesocosms: biological and chemical research in experimental ecosystems. Springer-Verlag, New York, p. 137-151

Manuscript first received: December 13, 1989

Revised version accepted: May 30,1990 